\title{
Surface and Sliding Wear Behaviour of Different Coatings and Steels
}

\section{Resistencia al desgaste por deslizamiento de diferentes recubrimientos y aceros}

\author{
Vera-Cárdenas E.E. \\ Universidad Politécnica de Pachuca, Zempoala Hgo., México \\ Correo:evera@upp.edu.mx \\ Vite-Torres M. \\ Instituto Politécnico Nacional, México DF \\ Correo:drmanulvite9@hotmail.com
}

\author{
Lewis R. \\ University of Sheffield, Department of Mechanical Engineering, \\ United Kingdom \\ Correo:roger.lewis@sheffield.ac.uk
}

Información del artículo: recibido: julio de 2010, reevaluado: octubre de 2010, aceptado: febrero de 2011

\begin{abstract}
In this work, the sliding wear behaviour of the coatings TiN, $\mathrm{CrN}$ and $\mathrm{WC} / \mathrm{C}$ applied on steel substrates was studied using a reciprocating wear test machine. All tests were carried out in dry conditions, at room temperature (20$23^{\circ} \mathrm{C}$ and $45 \%-50 \%$ relative humidity). The average sliding velocity was 0.08 $\mathrm{m} / \mathrm{s}$ and an amplitude of $2 \mathrm{~mm}$ was used. The applied loads were $11.76 \mathrm{~N}$ (Po $=1.74 \mathrm{GPa})$ and $7.84 \mathrm{~N}(\mathrm{Po}=1.52 \mathrm{GPa})$. Optical microscopy was used to observe the characteristics of wear scars and spalls and possible causes of their formation. The variation of the friction coefficient against the number of cycles was obtained. This was used to determine more precisely the time (number of cycles) where the coating presented the first signs of wear, in addition Energy Dispersive X-ray analysis (EDS) was performed, as well as Scanning Electron Microscopy (SEM) and hardness tests on the wear traces, which reinforced the previous observations. Thus it was possible to know the wear life of different coatings and possible causes of variation. Increasing the load was an important factor in the variation of wear life results. But it is also important to consider other factors such as surface roughness and thickness of coatings.
\end{abstract}

\section{keywords}

- coating

- wear

- substrate

- SEM 


\section{Resumen}

En este trabajo se estudió el comportamiento en desgaste por deslizamiento de los recubrimientos de TiN, CrN y WC/C aplicados sobre sustratos de acero. Las pruebas se realizaron con una máquina reciprocante en condiciones secas a temperatura ambiente $\left(20-23^{\circ} \mathrm{C}\right.$ y $45 \%-50 \%$ de humedad relativa). Se empleó una velocidad promedio de $0.08 \mathrm{~m} / \mathrm{s}$ y una amplitud de $2 \mathrm{~mm}$. Las cargas aplicadas fueron de $11.76 \mathrm{~N}(\mathrm{Po}=1.74 \mathrm{GPa})$ y de $7.84 \mathrm{~N}(\mathrm{Po}=1.52 \mathrm{GPa})$. Se realizó microscopía óptica para observar las características de las zonas de desgaste y sus posibles causas de formación. Se obtuvo gráficamente la variación del coeficiente de fricción con el número de ciclos. Estos datos se emplearon para determinar con mayor precisión el momento donde se presentaron las primeras señales del desgaste, adicionalmente se realizaron análisis por Difracción de rayos X (EDS), así como Microscopía Electrónica de Barrido (MEB) y microdureza, que reforzaron las observaciones previas. Fue posible conocer la duración de los recubrimientos y las cusas de su variación. El incremento en la carga de trabajo fue un factor importante en la variación de la vida al desgaste. Sin embargo, es importante considerar otros factores tales como la rugosidad y el espesor de los recubrimientos.

\section{Introduction}

Hard surface coatings have shown good performance in applications such as coating of cutting tools, stamping processes and forming and plastic injection tooling, amongst others (Vera et al., 2008). The aim of the present work was to study the wear and friction behaviour of coatings TiN, CrN and WC/C, when exposed to dry sliding conditions.

Different standard substrate materials for applications in bearings and gears were studied. It was of interest to know the wear performance of these coatings when sliding in dry conditions and with substrate materials not common in the literature (4320 steel, 8620 steel and 4140 steel).

One of the steels currently most commonly used in alloys for cutting tools and bearings is 100Cr6 steel. It is intended to find other alternatives in the types of steel that can be used for the applications mentioned when a thin film hard coating is applied to improve its wear resistance.

\section{Background}

A great deal of research work about sliding wear and friction with coatings involves 100Cr6 (AISI 52100) steel as a substrate material (Srikant et al., 2004). Tungsten carbide coatings have been applied to improve the life of extrusion dies, metrology parts and bearings. The microhardness ranges from 800 to $2100 \mathrm{HV}$. The properties such as microhardness and stoichiometry are strongly influenced by the deposition parameters (Bhusham et al., 1991). For soft films on hard substrates the load capacity decreases as film thickness increases, while for hard films on soft substrates the converse is true (Arnell et al., 1991). Some of the work carried out associated with the use of hard coatings is shown in table 1 .

\section{Experimental details}

Test apparatus

A reciprocating wear tester was used to carry out ballon-flat wear tests. The tester holds the ball specimens in a clamp on the reciprocating arm and flat disc specimens in a base unit via another clamp. The reciprocator (LDS V201 vibrator) is controlled by a function generator. Friction measurements were taken via a load cell SM-50N model, with a capacity of $50 \mathrm{~N}$ and a nominal rated output of $3 \mathrm{mV} / \mathrm{V}$. Figure 1 shows a photograph of the wear tester (Green et al., 2005).

\section{Test specimens}

The disc specimens have a diameter of $19 \mathrm{~mm}$ and a thickness of $3.5 \mathrm{~mm}$. The characteristics of the steel substrates and coatings used are shown in the table 2. A 100Cr6 steelball (diameter $4.75 \mathrm{~mm}$ ) was used. The coatings were applied by Oerlikon Balzers in Mexico. They were deposited with the PVD technique in a BAI 1200 machine with a high vacuum and at a temperature about $450^{\circ} \mathrm{C}$. 
Table 1. Features of some previous research on hard coatings

\begin{tabular}{|c|c|c|c|c|c|}
\hline Reference & Substrate material & Coating & Operating conditions & Applications & Results \\
\hline Polkar et al., 2006 & Austenitic steel & $\mathrm{TiCN}$ & $\begin{array}{c}\text { Temperature: } \\
500^{\circ} \mathrm{C} \\
\text { Load: } 15 \mathrm{~N} \\
\text { Linear speed: } 0.04 \mathrm{~m} / \mathrm{s} \\
\text { Tribometer: pin on disc } \\
\text { Sliding friction }\end{array}$ & Cutting tools & $\begin{array}{l}\text { The rises in temperature } \\
\text { increase the friction } \\
\text { coefficient and wear rates } \\
\text { on TiCN coatings. }\end{array}$ \\
\hline Löhr et al., 2006 & $100 \mathrm{Cr} 6$ & DLC & $\begin{array}{c}\text { Slip rolling friction } \\
\text { Po=1.5-2.3 GPa } \\
\text { Dry condition } \\
\text { Tribometer: twin disc } \\
\text { Speed: } 390 \mathrm{rpm}\end{array}$ & $\begin{array}{l}\text { Ball bearing races or } \\
\text { cages }\end{array}$ & $\begin{array}{l}\text { Acoustic Emission } \\
\text { provides an easy solution } \\
\text { for monitoring the wear } \\
\text { life of DLC coatings. }\end{array}$ \\
\hline Okumiya, 1999 & $100 \mathrm{Cr} 6$ & TiN, CrAlN, CrN & $\begin{array}{c}\text { Normal load: } 50 \mathrm{~N} \\
\text { Speed: } 3 \mathrm{~m} / \mathrm{s} \\
\text { Tribometer: two roller } \\
\text { Dry conditions }\end{array}$ & $\begin{array}{c}\text { Ball bearings, gear } \\
\text { wheels }\end{array}$ & $\begin{array}{l}\text { No positive effect of } \\
\text { rolling wear was found. }\end{array}$ \\
\hline Carvalho et al., 1998 & Tool steel & TiN & $\begin{array}{c}\text { Tribometer: pin on rig } \\
\text { tester } \\
\text { Oil lubricated conditions } \\
\text { Load: } 0.4-1.2 \mathrm{KN} \\
\text { Speed: } 500 \mathrm{rpm}, \mathrm{RCF}\end{array}$ & Cutting tools & $\begin{array}{l}\text { The fatigue life is at lower } \\
\text { stress levels significantly } \\
\text { influenced by both the } \\
\text { pre-treatment and the } \\
\text { final surface roughness of } \\
\text { the material. }\end{array}$ \\
\hline Singer et al., 1991 & M2 Tool steel & $\mathrm{TiN}$ & $\begin{array}{l}\text { Sliding contact } \\
\text { Reciprocating sliding } \\
\text { machine } \\
\text { Speed: } 0.1-1 \mathrm{~m} / \mathrm{s} \\
\text { Load: } 2 \text { to } 10 \mathrm{~N}\end{array}$ & $\begin{array}{l}\text { Cutting tools, precision } \\
\text { bearings }\end{array}$ & $\begin{array}{l}\text { Wear of TiN took place } \\
\text { in two stages. First an } \\
\text { air formed oxide layer to } \\
\text { TiN was transferred to } \\
\text { the ball, then oxide debris } \\
\text { transferred back to the } \\
\text { TiN surface. }\end{array}$ \\
\hline
\end{tabular}

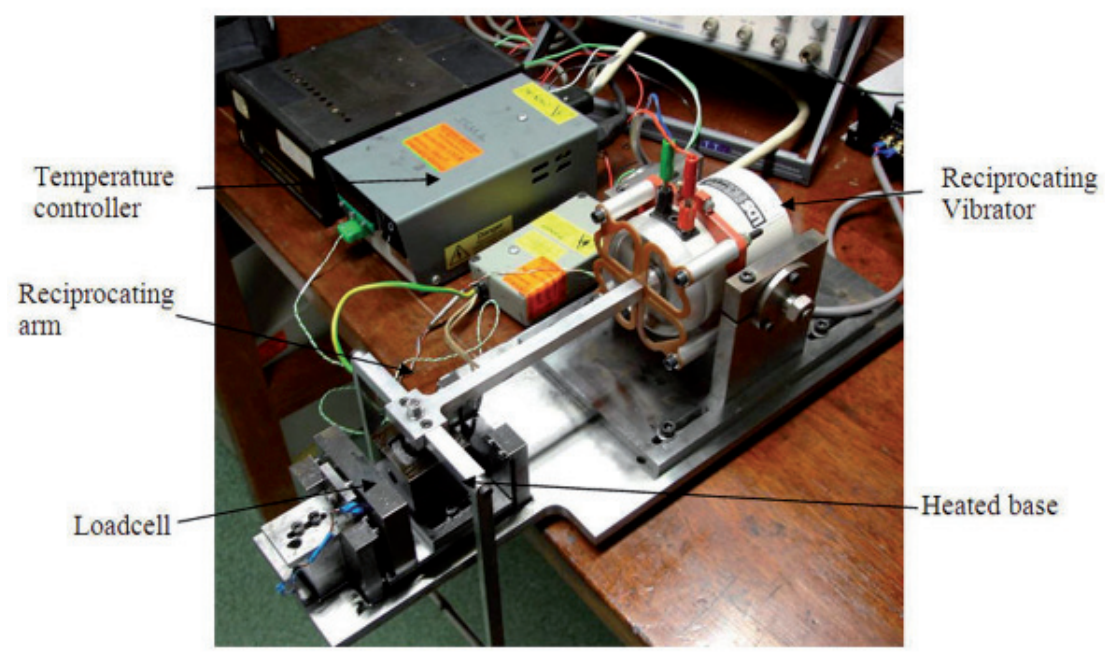

Figure 1. Universal reciprocating wear tester 


\begin{tabular}{|c|c|c|c|c|c|c|}
\hline $\begin{array}{c}\text { Substrate } \\
\text { Material }\end{array}$ & Coating & $\begin{array}{c}\text { Average } \\
\text { Hardness } \\
\text { HV }\end{array}$ & $\begin{array}{c}\text { Average } \\
\text { Roughness } \\
(\text { Ra } \mu \mathrm{m})\end{array}$ & $\begin{array}{l}\text { Young's } \\
\text { Modulus } \\
\text { GPa } \\
\text { (for the steel) }\end{array}$ & $\begin{array}{c}\text { Poisson's } \\
\text { ratio } \\
\text { (for the steel) }\end{array}$ & $\begin{array}{c}\text { Coating } \\
\text { Thickness } \\
\mu \mathrm{m}\end{array}$ \\
\hline 4320 steel & $\begin{array}{c}\text { TiN } \\
\text { CrN } \\
\text { WC/C } \\
\text { Without } \\
\text { Coating }\end{array}$ & $\begin{array}{c}1962 \\
995 \\
1258 \\
780\end{array}$ & $\begin{array}{l}0.25 \\
0.31 \\
0.44 \\
0.35\end{array}$ & 200 & 0.3 & $\begin{array}{l}3 \\
2 \\
3\end{array}$ \\
\hline 8620 steel & $\begin{array}{c}\text { TiN } \\
\text { CrN } \\
\text { WC/C } \\
\text { Without } \\
\text { Coating }\end{array}$ & $\begin{array}{c}2507 \\
1057 \\
1261 \\
720\end{array}$ & $\begin{array}{l}0.37 \\
0.21 \\
0.42 \\
0.32\end{array}$ & 200 & 0.3 & $\begin{array}{l}3 \\
2 \\
3\end{array}$ \\
\hline 4140 steel & $\begin{array}{c}\text { TiN } \\
\text { CrN } \\
\text { WC/C } \\
\text { Without } \\
\text { Coating }\end{array}$ & $\begin{array}{c}2248 \\
1023 \\
1147 \\
550\end{array}$ & $\begin{array}{l}0.21 \\
0.23 \\
0.38 \\
0.30\end{array}$ & 200 & 0.3 & $\begin{array}{l}3 \\
2 \\
3\end{array}$ \\
\hline
\end{tabular}

Table 2. Properties of specimens

\section{Test procedure}

The ball and flat test specimens were cleaned of any residue oxide layer or machining lubricant by washing in ethanol in an ultrasonic bath (Fisherbrand FB 11020). Subsequently, the ball and disc specimens were dried with hot air. The specimens were placed in the clamps of the test machine. Then the test parameters were introduced into the computer, such as: load, frequency and number of cycles. Finally the displacement amplitude was selected $(2 \mathrm{~mm})$. The maximum contact pressure was selected in such a way that wear would be produced with a low number of cycles. A Labview program was developed to set up the parameters of each test and collect the data generated, which was basically the friction coefficient versus time. On the screen it is possible to control the test parameters and follow the progression of the friction during every test. The tests performed with a load of $11.76 \mathrm{~N}$ were run to $72000 \mathrm{cy}-$ cles and tests with a load of $7.84 \mathrm{~N}$ were run to 108000 cycles.

This was predetermined with several preliminary tests, to see how many cycles were required to cause damage on the surface coatings. All coatings were tested at the same number of cycles. Not established a failure criterion to mark the end of the wear life of coating. Table 3 shows the operating conditions of the tests conducted.

Table 3. Test operating conditions

\begin{tabular}{|c|c|c|c|c|c|c|c|c|}
\hline $\begin{array}{c}\text { Substrate } \\
\text { Material }\end{array}$ & Coating & $\begin{array}{l}\text { Samples } \\
\text { tested }\end{array}$ & Test atmosphere & $\begin{array}{c}\text { Hertzian } \\
\text { pressure GPa }\end{array}$ & Load N & $\begin{array}{c}\text { Frequency } \\
\text { Hertz }\end{array}$ & $\begin{array}{l}\text { Amplitude } \\
\text { mm }\end{array}$ & Cycles \\
\hline 4320 steel & $\begin{array}{c}\text { TiN } \\
\text { CrN } \\
\text { WC/C } \\
\text { No coating }\end{array}$ & $\begin{array}{c}3 \text { of each } \\
\text { coating }\end{array}$ & $\begin{array}{c}20-23^{\circ} \mathrm{C} \text { and } 45 \% \\
-50 \% \text { relative } \\
\text { humidity }\end{array}$ & 1.74 and 1.52 & $\begin{array}{c}11.74 \text { and } \\
7.84\end{array}$ & 20 & 2 & $\begin{array}{c}72000 \text { and } \\
108000\end{array}$ \\
\hline 8620 steel & $\begin{array}{c}\text { TiN } \\
\text { CrN } \\
\text { WC/C } \\
\text { No coating }\end{array}$ & $\begin{array}{c}3 \text { of each } \\
\text { coating }\end{array}$ & $\begin{array}{c}20-23^{\circ} \mathrm{C} \text { and } 45 \% \\
-50 \% \text { relative } \\
\text { humidity }\end{array}$ & 1.74 and 1.52 & $\begin{array}{c}11.74 \text { and } \\
7.84\end{array}$ & 20 & 2 & $\begin{array}{c}72000 \text { and } \\
108000\end{array}$ \\
\hline 4140 steel & $\begin{array}{c}\mathrm{TiN} \\
\mathrm{CrN} \\
\mathrm{WC} / \mathrm{C} \\
\text { No coating }\end{array}$ & $\begin{array}{l}3 \text { of each } \\
\text { coating }\end{array}$ & $\begin{array}{c}20-23^{\circ} \mathrm{C} \text { and } 45 \% \\
-50 \% \text { relative } \\
\text { humidity }\end{array}$ & 1.74 and 1.52 & $\begin{array}{c}11.74 \text { and } \\
7.84\end{array}$ & 20 & 2 & $\begin{array}{c}72000 \text { and } \\
108000\end{array}$ \\
\hline
\end{tabular}




\section{Results}

\section{Friction behaviour}

The figure 2 shows the case of 4320 steel. It can be seen the difference in the friction behaviour for the three coatings. For TiN coating, was observed that the friction coefficient begins to rise from 500 cycles and for $\mathrm{CrN}$ was observed that the friction coefficient is greater with the minor load, and there is a great variation from 5000 cycles. This was probably caused by the removal of the coating. In the case of the WC/C coating, the friction coefficients obtained were very similar to those reported by other works (Joost et al., 2008; Bonny et al., 2008; Colik et al., 2006; Stewart et al., 2002) and by the supplier of the coatings (Balzers), was obtained a friction coefficient average between 0.13 and 0.15 .

In the figure 3 appears the friction behaviour of 8620 steel. For the TiN coating an increase in the friction coefficient is seen from 2000 cycles; this may be due to shedding of the coating. For $\mathrm{CrN}$, there is a higher friction coefficient reaching a value of 0.4 from 1800 cycles. In some cases the friction coefficient value was lower. For WC/C there were lower values in both load cases obtaining values until 0.1 . This may be due to the low coefficient of friction characteristic of WC/C, allowing a longer life. The shedding of this coating was in the form of small particles, which led to increased friction between the surfaces in contact. According to this, with the load of $11.76 \mathrm{~N}$ there is a greater contact pressure and the particles are displaced outside the contact zone, reducing the coefficient of friction, this situation was no presented with the lower load $(7.84 \mathrm{~N})$ in which, the contact pressure is less, some of the particles were trapped between the contact surfaces, increasing in some cases the coefficient.

The tests with 4140 steel (figure 4), show for TiN coating a decrease in the friction coefficient (0.25) from 5000 cycles. Most of the tests carried out with TiN, after 500 cycles, friction did not change much. It was further observed during some tests that the shedding of small particles occurred as a result of the sliding contact, causing an increase in the friction, because they act as abrasive bodies between the ball and coating (until 1000 cycles). This was confirmed with the analysis of wear and optical microscopy, shown later, where there are some indentations and scratches. For $\mathrm{CrN}$ coating, the coefficient of friction turned out very similar for both loads, and no indication was seen when the coating could have been detached. Unlike the TiN coating, no characteristic wear pattern was seen in the specimen. In all cases with $\mathrm{CrN}$ coatings, from 10000 cycles, there were no considerable variations of friction coefficient. Likewise it is noted that in most cases, the coefficient of friction is higher, with a load of $7.84 \mathrm{~N}$. For the WC/C coating, there was similarity of the coefficient of friction, ranging between 0.1 and 0.14 and there were no significant changes. It can be inferred that the test was not sufficient to achieve damage in the coating. One of the tests was continued until 200000 cycles, without significant damage in the coating.

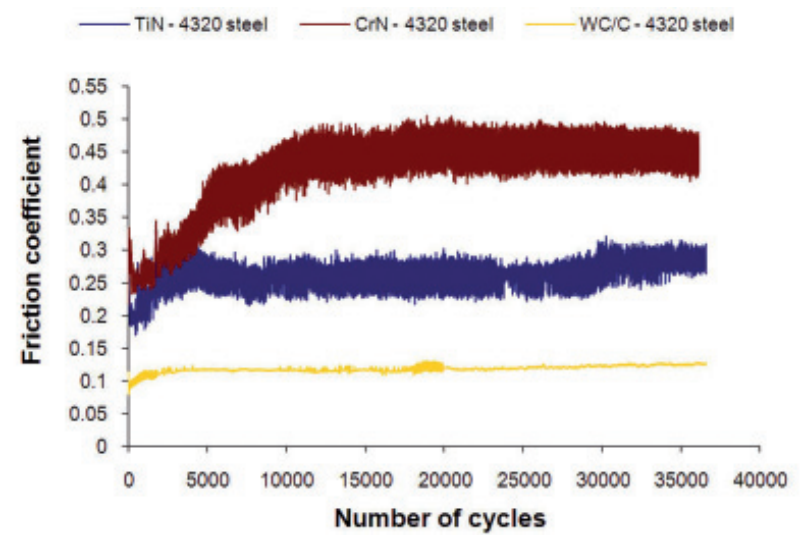

Figure 2. Friction behaviour of coatings in the 4320 steel

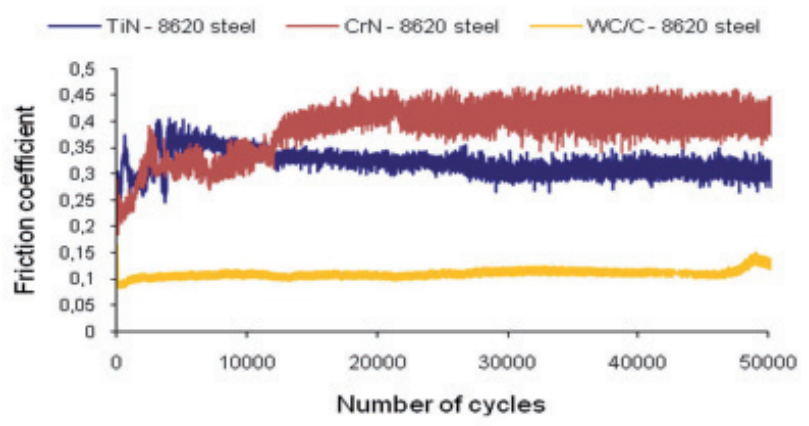

Figure 3. Friction behaviour of coatings in the 8620 steel

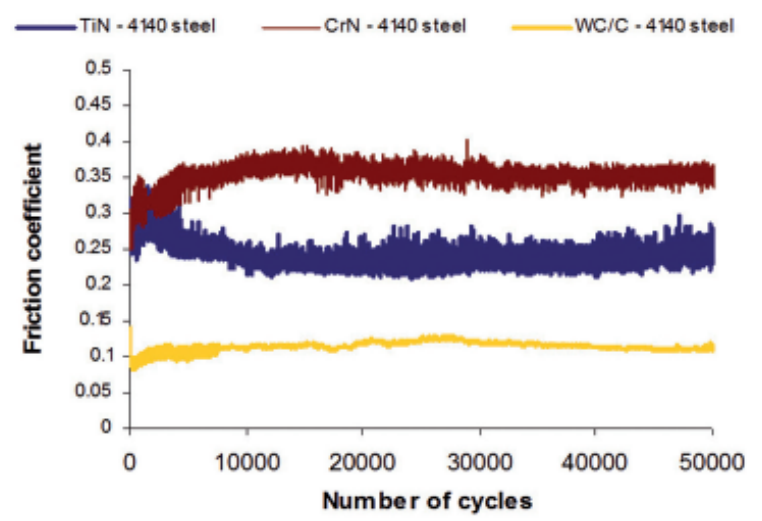

Figure 4. Friction behaviour of coatings in the 4140 steel 


\section{Wear rate}

The wear tests produced wear scars on the flat steel specimens and steel balls. There were measurable grooves on the flat specimens. The wear depth of each groove was measured using a Mitutoyo Surftest Profilometer. As the depth varied along the length of the groove a number of depth measurements (transverse to the length of the groove) were taken. The experimental average depth was taken from these measurements. From this information the volume of a 'perfect groove' could be calculated (Green et al., 2005). Wear rates were obtained from the scar profiles (some examples of which are shown in figure 5), which determined the size of the scar (depth, width and length). For the balls, wear dimensions were determined from measurements taken with an optical microscope.

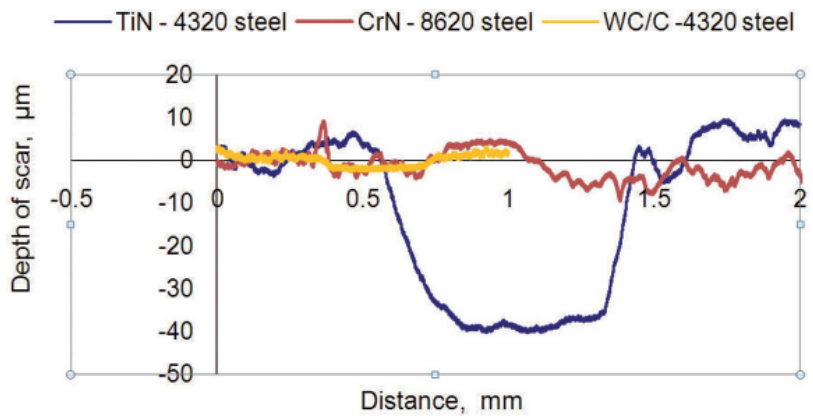

Figure 5. Roughness profiles

The specific wear rates in specimens of the different coatings and substrates are shown in figure 6 . In the case of TiN, the steel that presented greatest wear was 4320 steel with a load of $7.84 \mathrm{~N}$, then the 8620 steel with $7.84 \mathrm{~N}$ and after that the 4140 steel for a load of $11.76 \mathrm{~N}$. The smallest wear rate was with 8620 steel $(11.76 \mathrm{~N})$. The behaviour of the wear-load relationship for steels 4320 and 8620 was in agreement with expectations, i.e. higher load, greater wear. This also explains why on the load-friction coefficient relationship, there was greater detachment of the coating, but the coefficients of friction were lower. For the $\mathrm{CrN}$ coating, it was more difficult measure the wear volume to determine the wear rates, because the irregular form of the scar, it was used the average of the scars from the roughness profiles (figure 5). The greatest specific wear rate happened in the 4140 steel $(11.76 \mathrm{~N})$, and the lowest value was presented in the 4320 steel $(7.84 \mathrm{~N})$. For the WC/C coating, the wear was greater in the balls than in the coating (figures 6 and 7), due in part to the low coefficient of friction. In general, the wear rates in the specimens were similar in all substrates and types of load. The wear rates of subs- trates (without coating) displayed in figure 6, indicate excessive wear in the substrate and little wear in the balls (figure 7). The wear rates in balls are presented in figure 7. For the TiN, the greatest value was presented at the ball in contact with the 4320 steel $(11.76 \mathrm{~N})$ after this is the case of 8620 steel with a load of $7.84 \mathrm{~N}$ and then the 4140 steel with a load of $7.84 \mathrm{~N}$. The lowest wear rate was presented in the 4320 steel $(7.84 \mathrm{~N})$. For the balls in contact with $\mathrm{CrN}$, the highest wear rate happened in the ball against the 4140 steel with a load of $7.84 \mathrm{~N}$. In the balls in contact with $\mathrm{WC} / \mathrm{C}$, there are significant variations, especially in those with a load of $7.84 \mathrm{~N}$ and 108000 cycles. This suggests that in this case, the duration time of the test was more significant rather than the applied load. The greatest wear was presented in the ball against 8620 steel (load of $7.84 \mathrm{~N}$ ). This reflects the current application of this coating for cutting tools. The balls in contact with substrates, as was expected, the greatest ball wear was presented in the balls against the 4320 steel $(700 \mathrm{Hv})$, then the 8620 steel $(700 \mathrm{Hv})$ and finally in the 4140 steel $(550 \mathrm{Hv})$. Greater damage occurs with the implementation of higher loads and not with longer tests.

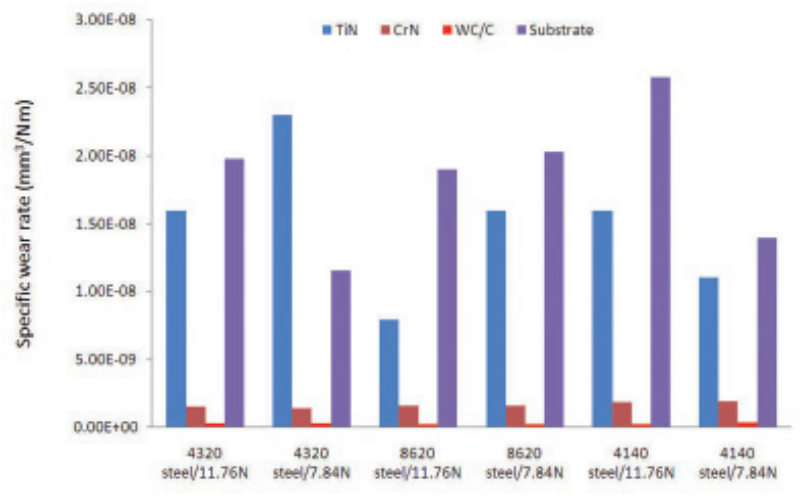

Figure 6. Wear rates in specimens

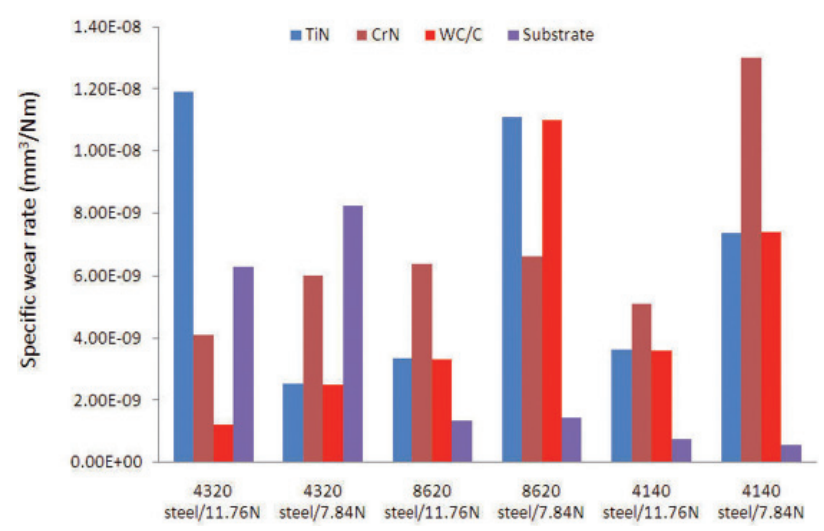

Figure 7 . Wear rates of $100 \mathrm{Cr} 6$ balls run against coatings 


\section{Optical microscope, SEM and EDS}

The figures 8 and 9 show some images of the wear scars of the coatings and balls respectively. In the case of TiN, it shows that the wear scar has a regular form, which helped to determine the volume of wear; the brighter areas are exposed substrate. The SEM micrographs (figures 10a and 10b) show the wear scars for 8620 steel with a TiN coating and the characteristics of wear within the scar. Detachment or complete disappearance of the coating can be observed in some areas. This can also be observed in the EDS analysis shown in figure 11a. Other work has shown similar results (De Bruyn et al., 1993).

In the $\mathrm{CrN}$ coating, it can be seen that clear scars were not formed as with the other coatings, instead isolated areas and irregular wear were seen. The dark areas are still coated and the clear areas are where the substrate material has been exposed (figure $8 b$ ).

To determine that in some areas the coating was removed it was necessary to test hardness, such as that shown for the steel 4320 with a load of $11.76 \mathrm{~N}$ (figure $8 \mathrm{e})$, where the wear scar produced by Vickers indentation appears, and whose measurement corresponded to the substrate $(700 \mathrm{HV})$. The SEM micrograph (figure $10 \mathrm{c}$ and $10 \mathrm{~d}$ ) shows that wear produced was irregularly shaped in the 4320 steel with a coating of $\mathrm{CrN}$. Figures 10 e and $11 \mathrm{~b}$ show a SEM micrograph and EDS graphic respectively, of 4140 steel with CrN coating, in the first, the clear areas represent removed coating (substrate) and the second shows how the content of Chromium has decreased significantly.

In the $\mathrm{WC} / \mathrm{C}$ coating, the scar was also produced in a regular form, but narrower than that produced with a TiN coating. The duration of the tests was not sufficient to cause considerable damage in the coating, and what is seen in the figures are wear scars but never with a completely detached coating. In the case of the substrate (without any coating), the wear scars produced were well-defined geometrically. A brighter area is visible in the image (figure 8c), which indicates a surface polishing by the contact with the ball and also severe plastic deformation.

For the balls, all images (figure 9) show the wear produced by the contact with different coatings in the 4140 steel substrate. In some cases as can be seen, the scars are big, which also can be verified in the wear ra- tes (figure 7). For the TiN coating, in some cases, adhesion of coating material on the ball was observed, presumably particles of TiN, however when making EDS (figure 11c), evidence was not found to confirm this. The diameter of scar in most cases was approximately $1.2 \mathrm{~mm}$. In some cases, grooves were found due to contact with the coating, such as 4320 steel $(7.84 \mathrm{~N})$ and 8620 steel $(11.76 \mathrm{~N})$. It may be noted in some situations, the wear scar is uniform (circular), but in most of cases they have an elliptical form or are irregular. This is mainly due to the direction of slip and the applied load, but may also be due to factors related to the adhesion of the coating and possible upset in holding the ball.

In the case of balls in contact with the coating of $\mathrm{CrN}$, most have an almost circular scar and wear was more regular in the surface coating and in the ball. This can be seen clearly in the images (figure 9) for the 4140 steel, which show the wear scar with well defined edges, without cracks. Within the scars, there are some small dark points, which were formed due to contact with third bodies, like wear particles of the same coating or ball material. In general it was found that there was less wear on the balls in contact with $\mathrm{CrN}$, than with TiN.

When in contact with the WC/C coating, the size of wear scar in the balls is much lower when compared with the previous coatings. The diameter of the scar is in the order of $0.6 \mathrm{~mm}$, almost half that of the scars worked with TiN and $\mathrm{CrN}$ coatings. As mentioned earlier, referring to the coefficient of friction and wear rates, this is mainly due to the low coefficient of friction offered by the WC/C. Even for example in the case of 4140 steel, the scar has a irregular form, with spots that are actually deeper scars, that could also have been caused by the original surface defects on the surface of the ball, which can be seen in the same image (figure 9). It is worth mentioning that in the case of this coating, the cycles to which the discs were subjected, were not sufficient to cause damage in the coating completely. See also figures 6 and 7 which show the vast difference between the wear in the coating and in the balls.

In the case of contact with the substrate, in all cases lower wear on the balls was observed than with coatings. The diameter of the scars was of the order of $0.55 \mathrm{~mm}$ and they had an elliptical form. It is worth mentioning that for these cases, the diameter was determined from the average of greater and lesser diameters. 

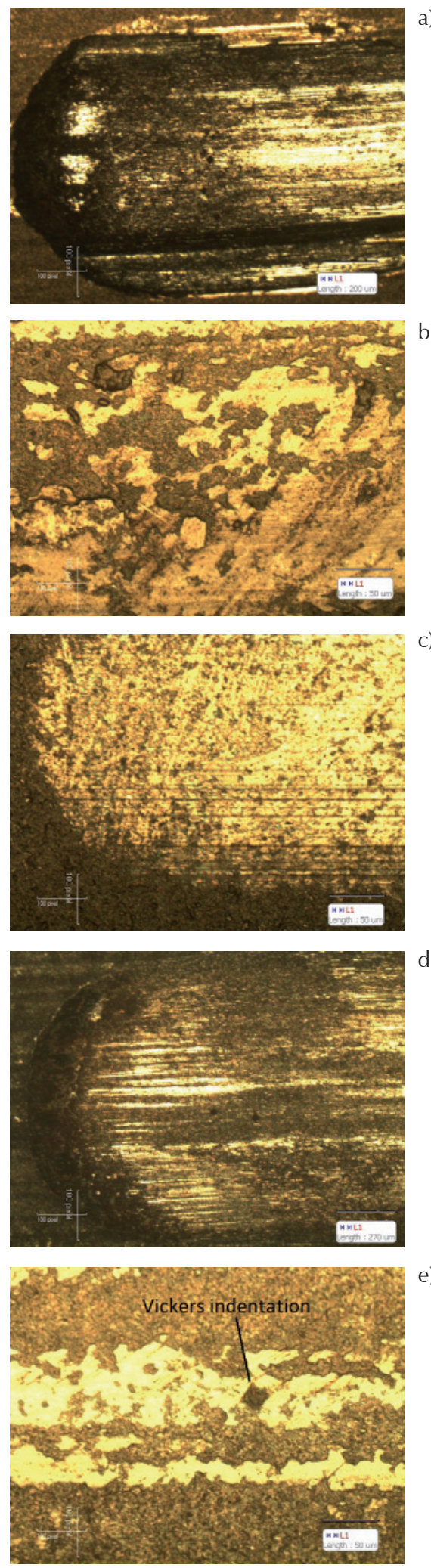

Figure 8. Optical microscope of 4320 steel: a) $\mathrm{TiN}$, b) $\mathrm{CrN}$, c) WC/C, d) No coating, e) CrN Hardness test
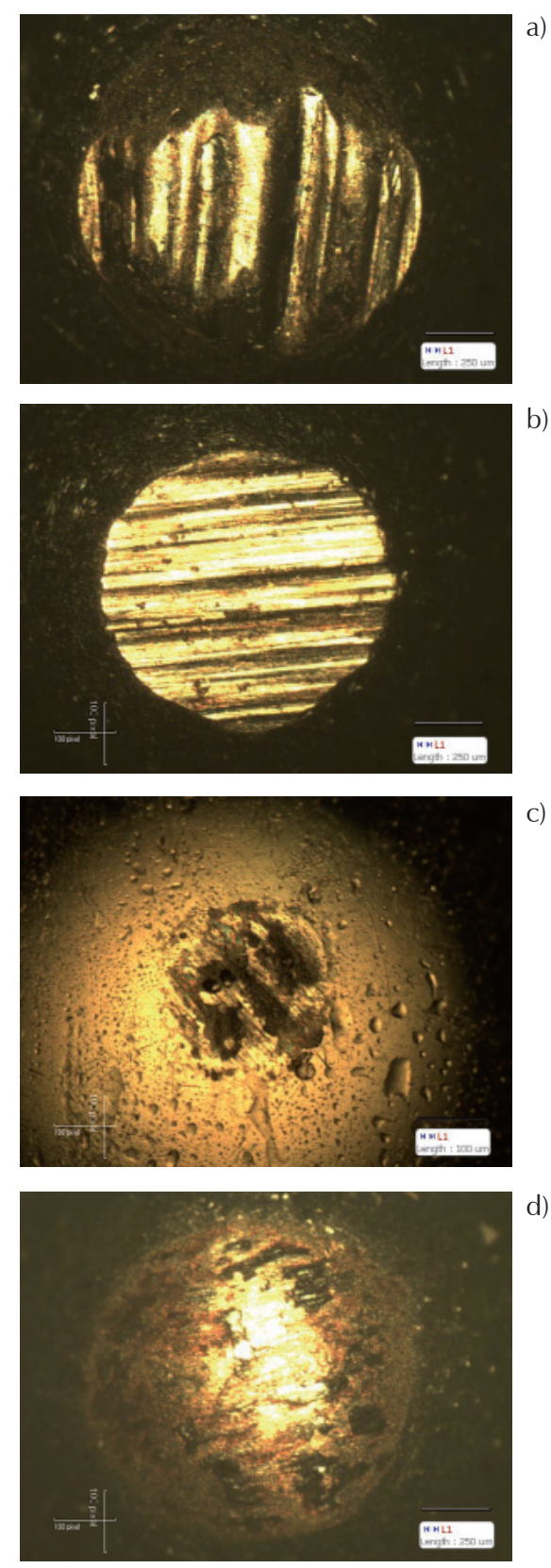

Figure 9. Optical microscope photos of balls (100Cr6) against 4140 steel: a) TiN, b) $\mathrm{CrN}$, c) WC/C, d) No coating 


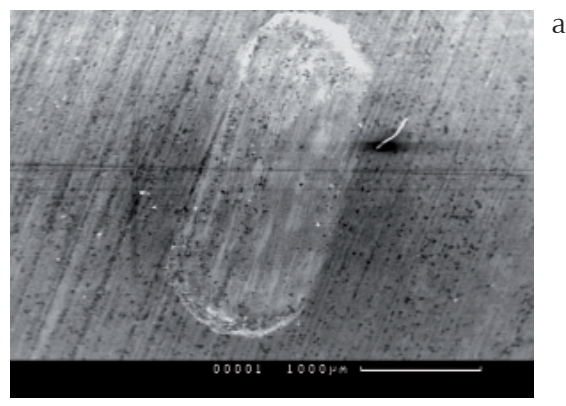

a)
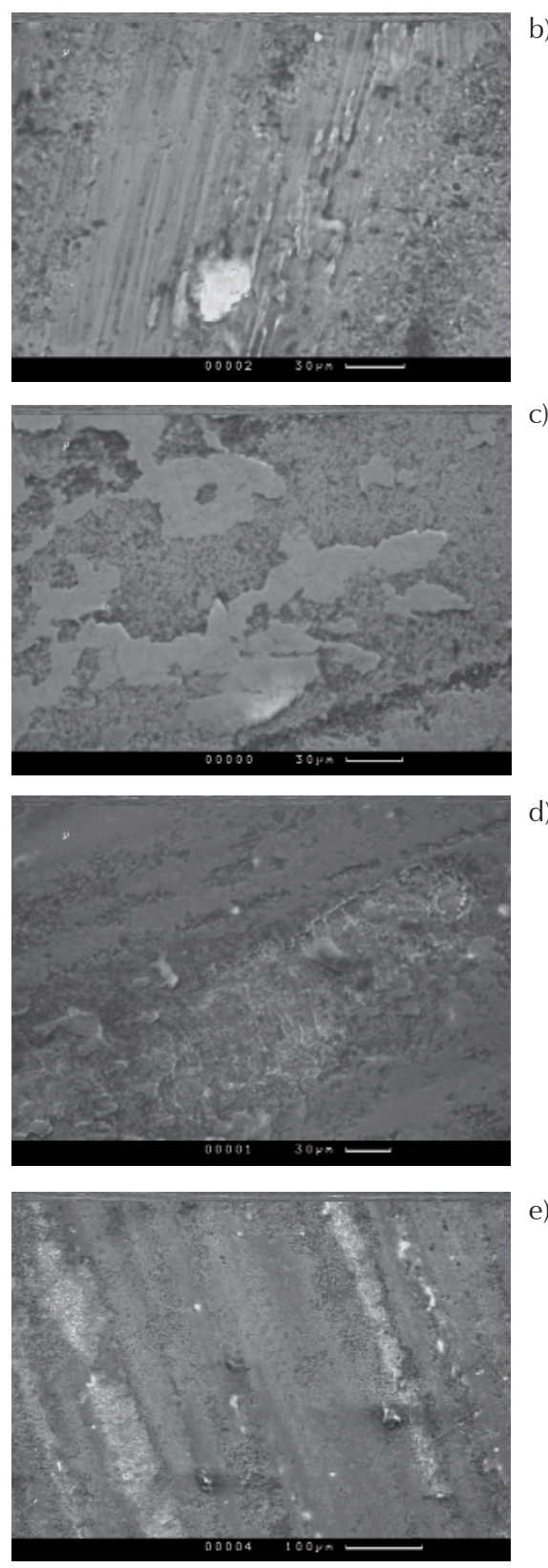

Figure 10. SEM micrographs of wear scar: a) and b) 8620 steel, TiN coating, c) and d) 4320 steel, CrN coating, e) 4140 steel, CrN coating

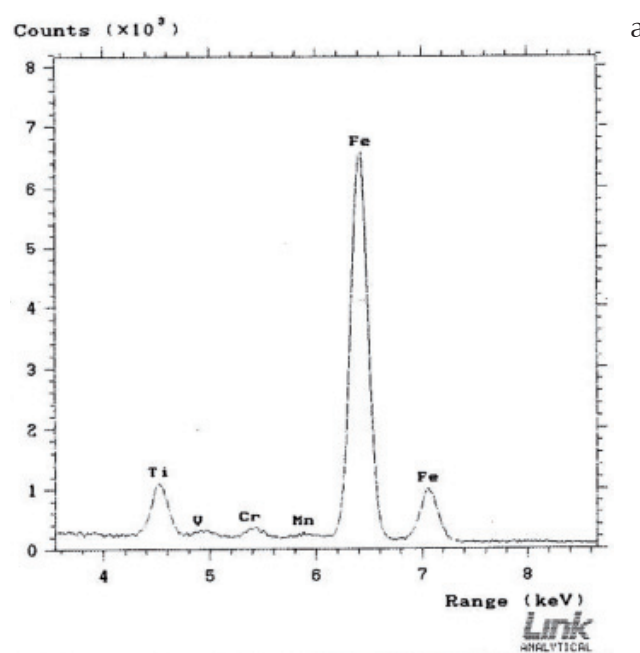

a)

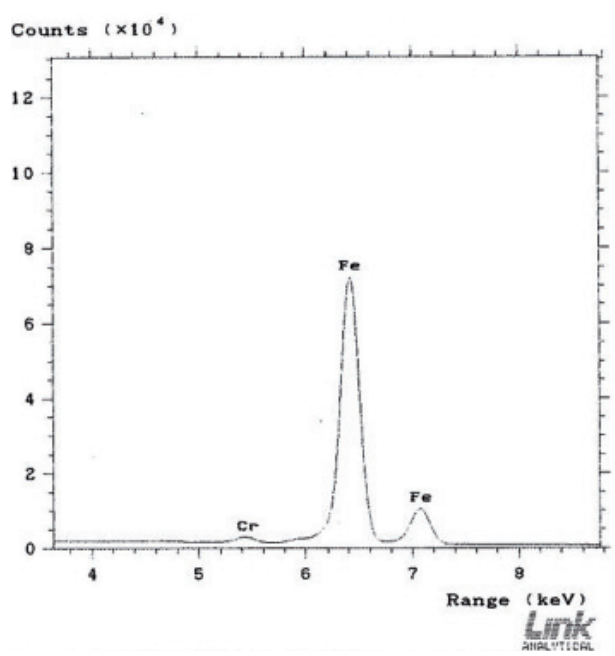

b)

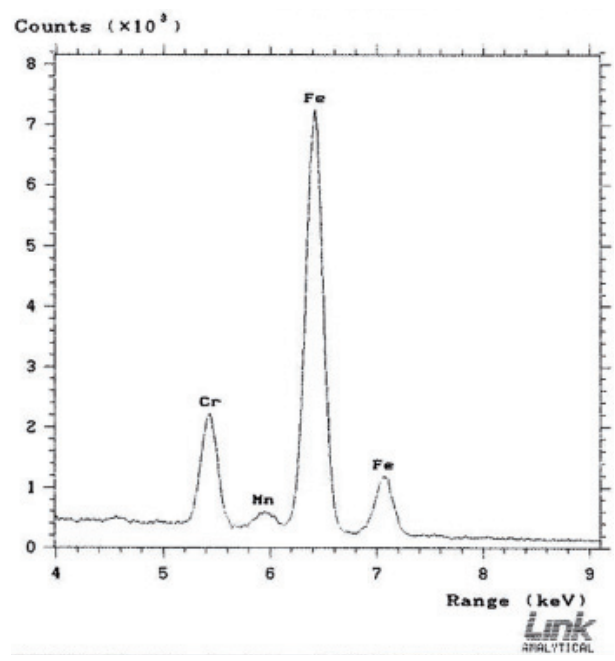

Figure 11. EDS graphics: a) 8620 steel specimen with a TiN coating, b) 4140 steel specimen with a $\mathrm{CrN}$ coating, c) $100 \mathrm{Cr} 6$ steel ball, in contact with a 4320 steel specimen with TiN coating 


\section{Discussion}

Sliding wear behaviour of TiN, $\mathrm{CrN}$, and WC/C coatings was evaluated in dry conditions, friction coefficients, wear rates and SEM micrographs were obtained, as well as EDS analysis, to determine whether there was transferred material of the coating to the ball, and to analyze the degree of wear of the coating on the substrate.

In the case of TiN coating, applied to steels AISI 4320,8620 and 4140 , the images in figure 8 , show a scar characterized by a failure mechanism initiated by abrasion. The wear in the coating was caused by contact with the ball. TiN particles removed, joined on the ball, which caused further acceleration of wear. In figure 8 can be seen that the mechanism of wear was similar in all tested steels. First there was a high detachment of the coating in the form of small particles, which were an important factor to accelerate the gradual wear of the coating. The particles, in direct contact between the surfaces, caused noise and vibration, creating instability in the system. This may have led to a rise in temperature in the contact area, further weakening the coating. In most cases the tests were run until the total detachment of the coating, and even appear to wear on the substrate (shiny appearance at the scar) occurred.

In the case of the ball, in this type of coating there was not adherence of TiN on the ball, corroborated by EDS analysis. In some cases uniform wear was not observed on the ball, forming irregular areas, perhaps due to the presence of abrasive particles that are displaced from the centre toward the sides. This phenomenon was observed mainly in tests with the load of $11.76 \mathrm{~N}$.

In the case of the $\mathrm{CrN}$ coating, it was difficult to identify the mechanism of failure. The wear originated does not follow a traditional pattern as in the case of other coatings. Uniform wear was not seen and it was difficult to detect visually the release of the coating. Wear particles were observed to a lesser amount than with the TiN coating. Adhesion of $\mathrm{CrN}$ was not observed in the ball. The wear in the ball was uniform and larger compared with TiN and WC/C. This coating had better wear resistance than $\mathrm{TiN}$. The $\mathrm{CrN}$ coating acts as a repellant to the mechanisms of failure of traditional sliding wear, resulting in small areas of wear of the coating that are isolated and irregularly shaped (figure 8). Some tests lasted until 150000 cycles without any changes in the surface or size of the areas of wear. Noise and vibration were not apparent. As can be seen in figure 6, wear rates on the ball were greater than in the other coatings, reinforcing the idea of the high wear resistance of the $\mathrm{CrN}$. This coating, acted efficiently in this type of wear, under the specific conditions of the tests con- ducted, showing little wear on the surface of the three tested steels. This explains the recent high use of this type of coating on different applications of mechanical parts subject to sliding wear, including cutting tools, guides, dies, and so on.

The $\mathrm{WC} / \mathrm{C}$ coating showed the best performance in this work. The wear rates of this coating and balls were the lowest of the three coatings employed (figures 6 and 7). The low coefficient of friction (0.15 - 0.2. see figure 3 ) is the most important factor that led to low wear rates. The wear scar apparently shows a detachment of the coating (figure 8). However, closer examination shows this is polishing on the surface and the coating is actually intact. In the case of the ball in contact with this coating, figure 9 shows that traces of wear are smaller than in the case of other coatings. In trials with this coating, particles did not appear that could act as an abrasive in the contact area and that might have accelerated wear. Under the conditions of the experiments significant wear did not occur in tests are left to run for more than 3 hours (200,000 cycles).

In the experiments outlined in this paper studying sliding wear, TiN and $\mathrm{CrN}$ showed a better performance in comparison with results obtained previously in RCF tests (Vera et al., 2008). These results showed poor resistances to this kind of wear (RCF), and the coatings rapidly detached, particularly the TiN.

There was no significant difference among the three substrates. However, one can see that the results of wear rates and scars seen by optical microscopy and SEM, in most cases, the 4320 steel gives slightly better wear performance than the other two. According to the chemical composition of the substrates, the major difference between them is the content of nickel. This gives the properties of high strength, yield strength greater than carbon steels, high temperature resistance and corrosion. The 4320 steel has a high percentage of nickel $(1.62-2 \%)$, which reinforces the veracity of the results achieved.

Substrates AISI 4320, 8620 and 4140 used in this study showed acceptable properties to resist sliding wear and provide an efficient alternative for implementation under the conditions used in this work.

\section{Conclusions}

According to studies of friction coefficient and wear behaviour of the TiN, $\mathrm{CrN}$ and $\mathrm{WC} / \mathrm{C}$ coatings deposited onto 4320 steel, 8620 steel and 4140 steel substrates tested in dry conditions at room temperature and analysis of the wear scars using optical microscopy and SEM, the conclusions are as follows: 
- There were no significant changes in the coefficient of friction between the three substrate materials tested. But significant changes among the three coatings used were found, especially with the WC/C coating.

- In some cases, the variation of the friction coefficient against the number of cycles indicated the removal of the coating, mainly with the $\mathrm{CrN}$ coating.

- In most cases, there were no significant variations of the coefficient of friction between the two loads used in this study, especially with the WC/C coating.

- The behaviour of specific wear rates for TiN coating was higher in the specimens and lower in the balls. In the case of $\mathrm{CrN}$ and WC/C coatings, the opposite happened.

- The WC/C coating, presented the best wear resistance by sliding, when it was tested until 200000 cycles, without substantial damage.

- It is feasible to use these substrates subjected to sliding wear, providing another alternative for the selection of materials in the manufacture of mechanical elements subjected to this type of wear.

\section{Acknowledgements}

The work described in this paper has been supported by the Tribology Group, of the University of Sheffield, UK. The authors acknowledge Balzers Group for the deposition of PVD TiN, CrN and WC/C coatings on steel substrates.

\section{References}

Arnell R.D. et al. Tribology: Principles and Design Applications, Macmillan Education LTD, 1991.

BonnyK., De Baets P., Ost W. Influence of Secondary Electro-Conductive Phases on the Tribological Response of Zirconia-Based Composites Against WC-Co Cemented Carbide, Nordtrib, Tampere, Finland, 2008.

Bhushan B., Gupta B.K. Handbook of Tribology: Materials, Coatings and Surface Treatments, McGrawGill, 1991.
Carvalho N.J.M., Huis A.J., In' T Veld J., De Hosson Th. Interfacial Fatigue Stress in PVD TiN Coated Tool Steels Under Rolling Contact Fatigue Conditions. Surf. Coat. Technology, 105:109116. 1998.

Celik E., Culha O., Uyulgan B. Assessment of Microstructural and Mechanical Properties of HVOF Sprayed WC-based Cermet Coatings for a Roller Cylinder. Surf. Coat. Technology, 200: 4320-4328. 2006.

De Bruyn K., Celis J.F., Roos J.R. Coating Thickness and Surface Roughness of TiN Coated High Speed Steel in Relation to Coating Functionality. Wear, 166:127-129. 1993.

Green D.A., Lewis R., Dwyer-Joyce R.S. The Wear Effects and Mechanisms of Soot Contaminated Automotive Lubricants, IMechE, Part J. Journal of Engineering Tribology, 220:159-169. 2005.

Joost R., Pirso J., Viljus M. The Effect of Carbon Content on the Mechanical and Tribological Properties of WC-Co Cemented Carbides, Nordtrib, Tampere, Finland, 2008.

Löhr M., Spaltmann D., Binkowski S. In Situ Acoustic Emission for Wear Life Detection of DLC Coatings During Slip-Rolling Friction. Wear, 260:469-478. 2006.

Okumiya M., Griepentrog M. Mechanical Properties and Tribological Behaviour of TiN-CrAlN and CrN-CrAlN Multilayer Coatings. Surf. Coat. Technology, 112:123-128. 1999.

Polcar T., Novák R., Siroký P. The Tribological Characteristics of TiCN Coating at Elevated Temperatures. Wear, 260:40-49. 2006.

Singer I.L., Fayeulle S., Ehni P.D. Friction and Wear Behaviour of TiN in Air: the Chemistry of Transfer Films and Debris Formation. Wear, 149:375-394. 1991.

Srikant-Nekkanty M.E.W. Indentation Damage to Boron CarbideDLC Coatings with Different Compositions. Surf. Coat. Technology, 183:1-9. 2004.

Stewart S., Ahmed R. Rolling Contact Fatigue of Surface CoatingsA Review. Wear, 253: 1132-1144. 2002.

Sue J.A., Troue H.H. Friction and Wear Properties of Titanium Nitride Coating in Sliding Cont.

Vera E.E., Vite M., Vite J., Hilerio I. Comparative Analysis of the Experimental Results of Wear by Rolling Contact Fatigue ( $r c f$ ) of Steel AISI 4140 Base and with Superficial Covering of Nitriding, Hard Chromium and TiN, Nordtrib (2008)-116-31, Tampere, Finland. 


\section{About the authors}

Edgar Ernesto Vera-Cárdenas. He received the B.S. degree in mechanical engineering (ME) from Instituto Tecnologico de Pachuca in 1995. In 2003, he received his master degree in ME from Instituto Tecnologico de Celaya and his PhD degree in ME from Instituto Politecnico Nacional, in 2009. He was a visiting PhD student at University of Sheffield, UK, in 2008. He has published research papers in different national and international conferences. Currently he is a research professor at the coordination of mechatronics of the Universidad Politecnica de Pachuca.

Manuel Vite-Torres. He received the B.S. degree in physics from the Faculty of Science of the UNAM, in 1979. He received his PhD degree in applied physics at the Faculty of Applied Physics and Nuclear Engineering from the Technical University of Prague, Czech Republic. He is member of the National System of Researchers (SNI) level 1 and active evaluator of CONACYT and Chilean System of Science (CONICYT). He has directed over 25 undergraduate thesis and 20 postgraduate thesis. Currently he is a research professor at the SEPI-ESIME-IPN developing projects related to tribology.

Roger Lewis. He graduated from the University of Sheffield in 1996 with a MEng in Mechanical Engineering and continued to work at Sheffield towards a $\mathrm{PhD}$ in the Tribology Research Group. He then had posts as a Research Associate and Teaching Fellow in the Department. In 2001 he was awarded the Tribology Trust Bronze Medal and in 2003 received a Brian Mercer Award for Innovation from the Royal Society. He is a Chartered Engineer and a Fellow of the Institution of Mechanical Engineers. He is currently a member of the IMechE Tribology Group and Railway Division Young Members committees. Became a lecturer in the Department in 2002 and was promoted to Senior Lecturer in 2006. 